\title{
Corporate diplomacy and family firm longevity
}

Article

Accepted Version

Ciravegna, L., Kano, L., Rattalino, F. and Verbeke, A. (2020)

Corporate diplomacy and family firm longevity.

Entrepreneurship Theory and Practice, 44 (1). pp. 109-133.

ISSN 1540-6520 doi:

https://doi.org/10.1177/1042258719838477 Available at https://centaur.reading.ac.uk/84157/

It is advisable to refer to the publisher's version if you intend to cite from the work. See Guidance on citing.

To link to this article DOI: http://dx.doi.org/10.1177/1042258719838477

Publisher: SAGE Publications

All outputs in CentAUR are protected by Intellectual Property Rights law, including copyright law. Copyright and IPR is retained by the creators or other copyright holders. Terms and conditions for use of this material are defined in the End User Agreement.

\section{www.reading.ac.uk/centaur}

\section{CentAUR}

Central Archive at the University of Reading 
Reading's research outputs online 


\title{
CORPORATE DIPLOMACY AND FAMILY FIRM LONGEVITY
}

\section{Luciano Ciravegna, Liena Kano, Francesco Rattalino, Alain Verbeke}

\begin{abstract}
We discuss family firm longevity building upon a new conceptual lens, informed by transaction cost economics (TCE), but augmented with corporate diplomacy thinking. Family firms, because of their superior foundation of bonding social capital (interpreted here as a firm-specific, transaction cost reducing governance mechanism), have an intrinsic advantage vis-a-vis nonfamily firms with regards to utilizing network ties supportive of longevity. Most family firms, however, fail to leverage effectively this governance tool to achieve longevity, due to bifurcation bias (BB), i.e., the unchecked prioritization of assets and relationships that hold affective value for the family. We propose that corporate diplomacy, through its three process steps, familiarization, acceptance, and engagement, can help the family firm augment its baseline reservoir of social capital, and allows improved economizing on contracting challenges that endanger its survival. Externally, corporate diplomacy helps economizing on expressions of BB in relationships with outside stakeholders, thus augmenting bridging social capital. Internally, it can address biased treatment of family versus non-family human assets, thereby augmenting bonding social capital. Inter-generationally, corporate diplomacy supports access to, and improved reliance upon the firm's social capital by next generation family members. The family firms that focus on corporate diplomacy processes and the resulting social capital creation, greatly improve their chances of longevity.
\end{abstract}

Key words: family firm, family firm longevity, family firm longevity paradox, transaction cost economics, bifurcation bias, corporate diplomacy 


\section{INTRODUCTION}

Few family firms, or firms where more than one generation of family is involved in ownership, leadership and/or decision-making (Bennedsen \& Foss, 2015), survive for more than three generations (Stamm \& Lubinski, 2011). Yet, most of the world's oldest surviving organization (excluding educational institutions, governments, and religious institutions), such as Gekkeikan, a Japanese firm brewing sake since the 1600s, are in fact family firms (Bennedsen \& Henry, 2016; World Atlas, 2018). This variance in family firms' lifespan presents a family firm longevity paradox, which we attempt to explain in this study.

Prior transaction cost economics (TCE) work on family firms explains the first part of the paradox, that is, the low survival rates of family business. Bifurcation bias (BB), or de facto preferential treatment of assets that have affective value for the firm (Jennings, Dempsey, \& James, 2018; Kano \& Verbeke, 2018; Verbeke \& Kano, 2012), creates additional bounded rationality challenges (related to scarcity of mind) and bounded reliability ones (related to scarcity of making good on open-ended promises), and can threaten firm survival. Family firm research based on other theoretical foundations, such as stewardship theory and the socioemotional wealth (SEW) perspective, focuses on the second part of the paradox - the reasons why family firms may be better placed at surviving in the long term than non-family firms. Such better odds are ascribed to family firms' long-term orientation (LTO), or a particular way of viewing time and making intertemporal choices (Le Breton-Miller \& Miller, 2006). LTO is argued to stem from family firms' prioritization of transgenerational continuity (Memili, Chrisman, \& Chua, 2011; Miller \& Le Breton Miller, 2005, 2006; Jaskewicz, Combs, \& Rau, 2015), as well as from family members' willingness to 'steward' the firm in the long run due to the alignment of interests between owners and managers (Corbetta \& Salvato, 2004; Davis, Schoorman, \& Donaldson, 1997). Many family firms share the features that the literature has 
identified as supportive of LTO, such as the desire for transgenerational wealth transmission. However, the pursuit of transgenerational continuity can, in itself, threaten business survival, if prioritized indiscriminately, without selecting economizing governance practices supportive of the long-term health of the business (Kano \& Verbeke, 2018). ${ }^{1}$

Most TCE work on family firms focuses on firm-level governance, but TCE argues that firm survival depends upon the ability to economize on both micro-level contracting challenges in the realm of bounded rationality and reliability, and equivalent challenges from macro-level shift parameters (changes in the broader political, institutional, social and economic contexts). Williamsonian (1996) macro-level shift parameters can vitiate governance tools that firms adopt to economize on bounded rationality and reliability, for example, when government agencies introduce abrupt changes in the legal framework relied upon when signing contracts with third parties. Only firms with the ability to adapt to these macro-level changes can achieve longevity.

It has been argued that some family firms command a unique governance mechanism, namely superior social capital, and are able to sustain this tool in the long term and transmit it trans-generationally. These firms are thereby supposedly apt at the sort of stakeholder management that helps economizing on macro-level shifts (Arregle, Hitt, Sirmon, \& Very, 2007; Pearson, Carr, \& Shaw, 2008). Yet, few family firms successfully utilize this governance mechanism facilitating long-term survival, because of dysfunctional $\mathrm{BB}$, which prevents them from effectively developing and deploying their social capital outside of the context of affective family-based ties. Achieving longevity implies augmenting the social capital stemming from the family with new relationships to support efficient transactions, and ensuring that these relationships are routinely assessed on the basis of their efficiency properties.

\footnotetext{
${ }^{1}$ Governance practices refer in our paper to established routines through which managerial choices are made and implemented, in the realm of selecting the firm's boundaries, structuring the interactions with external stakeholders and engaging in internal organizational design (including fine-grained practices at the functional level).
} 
We explore how family firms can address these challenges by taking on board insight from the international relations literature, more specifically research on corporate diplomacy. Corporate diplomacy can be described as a set of processes whereby corporations achieve recognition as value-creating partners in broader society. They do this through aligning their corporate values with societal value systems, thereby augmenting their social capital. Corporate diplomacy thinking suggests actionable paths in the process sphere to strengthen social capital as a governance mechanism, allowing inter alia, the favourable repositioning of the firm in its broader environment (Ordeix-Rigo \& Duarte, 2009). In the context of family firms, which from the outset supposedly command superior social capital, built around family ties, the nurturing of corporate diplomacy processes is instrumental to achieving longevity. Corporate diplomacy helps family firms economize on $\mathrm{BB}$, at the micro and macro levels, and transmit economizing practices across generations of family managers.

The remainder of this paper is structured as follows. We start by summarizing extant research on family firm longevity and provide a brief review of core TCE arguments in the context of family firms. Next, we review the concept corporate diplomacy. We then develop our conceptual model and explain how family firms use corporate diplomacy processes to adapt to their macro environment, achieve firm-level governance efficiency, and transmit successful practices through generations. We conclude with summarizing our findings and discussing implications for future research. While this is a deductive, theory-driven study, our ultimate goal is to attain an in-depth understanding of drivers of longevity in real-world family firms. We rely on examples of old, multi-generational family firms to support our conceptual arguments.

\section{FAMILY FIRM LONGEVITY}

The family firm literature suggests that the pursuit of non-economic goals, such as a desire for dynastic succession, emotional attachment of the family to the business, and identification with it, 
creates incentives for long-term survival (Gomez-Mejia, Haynes, Núñez-Nickel, Jacobson, \& Moyano-Fuentes, 2007). Further, the desire to transmit wealth to future generations implies that family firms often extend the time horizon of expected returns and are willing to invest in longterm projects, a phenomenon labelled 'patient capital' (Sirmon \& Hitt, 2003).

Scholars espousing the stewardship perspective argue that family members are more likely to be 'stewards' of the firm, investing their personal relational and financial capital for the survival and success of the business, and avoiding short-term return-driven behavior that might compromise long-term survival (Davis et al., 1997; Le-Breton Miller \& Miller, 2011). The stewardship perspective assumes that family members act in pursuit of organizational interests, and that this alignment of individual and organizational goals explains the ability to survive over the long term (Corbetta \& Salvato, 2004). However, family members may act in pursuit of selfinterest in ways that do damage to the firm, for example, by shirking or even pillaging its resource base (Schultze, Lubatkin, Dino, \& Buchholtz, 2001). Stewardship behavior does not automatically eliminate 'basic truths' about the nature of individuals, such as bounded rationality and reliability (Chrisman, 2018): that is, even when family managers purposefully act as stewards, their inherent bounded rationality and reliability may prevent them from achieving intended pro-organizational outcomes, unless there are control mechanisms in place to economize on information asymmetries and commitment non-fulfilments. Yet, evidence suggests that family managers are often reluctant to implement formal monitoring and control systems (Dyer, 2006). Stewardship behaviour may actually discourage formal controls (Corbetta \& Salvato, 2004; Hernandez, 2012). Stewardship, on its own, can therefore not explain longevity, nor can it explain why many family firms do not survive past the second generation.

Lumpkin and Birgham (2011, p. 1050) define LTO as: "the tendency to prioritize the long-range implications and impact of decisions and actions that come to fruition after an 
extended time period." They argue that families where decision makers are guided by LTO should be more apt at surviving in the long-term. Le Breton-Miller and Miller (2011, p. 1171) argue that the key to understand longevity is multi-temporality, or "the ability to achieve enduring success by meeting both short and long-term challenges." Here, the emphasis is not only on the importance of pursuing long-term objectives, but also on doing so in ways that do not compromise short-term performance, that is, balancing a long-term horizon with the ability to respond to market requirements in the short run. As suggested by Sharma \& Manikutty (2005, p. 295): "For firms desirous of longevity as family firms ... changes in the environment require strategic responses on the part of a firm (such as readjustment of the business portfolio and divestment of unproductive resources), so as to enable regeneration and renewal".

Yet, family firms are known to be resistant to the types of changes mentioned by Sharma \& Manikutty (2005); it has been argued that these firms are often less innovative, enter fewer new markets, and are less involved in patenting (Betrand \& Shoar, 2006; Gómez-Mejía, Makri, \& Larraza-Kintana, 2010). Neither stewardship theory, nor work on LTO can therefore explain why some family firms achieve high longevity, whereas many more do not. In contrast, the TCE theory of the family firm may be more promising in explaining the above duality, and providing predictions as to when high longevity can be expected, as we explain below.

\section{TCE AND THE FAMILY FIRM}

TCE's core premise is that economic actors will select and retain the most efficient governance mechanisms to conduct exchanges, by aligning governance mechanisms with the attributes of a given transaction (or a set of transactions), in a cost-economizing way (Hennart, 1994;

Williamson, 1981, 1996). The Williamsonian version of TCE is built upon three core assumptions: asset specificity, bounded rationality, and opportunism (Williamson, 1996). In subsequent work, the concept of bounded reliability was introduced as an alternative to the 
narrow assumption of opportunism (Kano \& Verbeke, 2015; Verbeke \& Greidanus, 2009). ${ }^{2}$

Ultimately, sustainability of governance (which, in the case of family firms, means survival and longevity as family businesses) results from the firm's ability to select and deploy a mix of governance mechanisms that allow economizing in contracting, and to adjust these mechanisms over time (Hennart, 1994).

The sustained efficiency of governance mechanisms (relative to real world alternatives) is tied to macro-level shift parameters characterizing the environment in which the firm operates. These shift parameters, e.g., "changes in property rights, contract laws, norms, customs, and the like" (Williamson, 1996, p. 223), represent the essence of the evolution of the firm's broader environment, and must be taken into account in the unfolding of governance over time.

Changes in the macro environment can be abrupt, for example because of revolutions, and coups d'état. When these changes occur, firms become exposed to new bounded reliability issues, because extant economizing instruments, such as previously optimal market contract clauses, may become misaligned (Gao, Zuzul, Jones, \& Khanna., 2017). Macro-level shocks may negatively affect third parties the firm has contracts with, making them unable to fulfill their commitments to the firm.

Longevity requires the ability to economize not only on macro-level shocks, but also, more broadly, on macro-level institutional frailties (e.g., a weak property rights regime), which can exacerbate bounded rationality and bounded reliability challenges in all transactions, and thus

\footnotetext{
${ }^{2}$ Bounded reliability explains instances of commitment non-fulfillment that occur due to a variety of reasons including, but not limited to, strong-form self-interest. These reasons fall into three distinct categories: (1) opportunism; (2) benevolent preference reversal; and (3) identity-based discordance. Scholars espousing the concept of bounded reliability argue that governance systems should be designed so as to economize on bounded rationality and bounded reliability (and not exclusively opportunism) of economic actors involved in transactions. In this study, we adopt the concept of bounded reliability, rather than the narrower concept of opportunism, as a core behavioral assumption.
} 
create uncertainties that hinder contracting generally, e.g., when contracts are unlikely to be enforceable through the route of legal recourse.

Comparative efficacy of governance mechanisms varies with the macro environment on the one hand, and the micro-level attributes of economic actors - that is, bounded rationality and reliability - on the other (Williamson, 1996). In a family firm, the core behavioural assumptions of TCE take on a unique form. First, family firms are characterized by family-based asset specificity (Verbeke \& Kano, 2010), whereby, e.g., family members employed by the firm, heritage product lines or physical resources, or particular ingrained routines, cannot be adjusted and redeployed as quickly and efficiently as in a firm with dispersed ownership (Pollak, 1985). Second, because of family-based asset specificity, family firms experience unique bounded rationality and bounded reliability challenges, whereby family-based resources and non-family ones (e.g., professional managers) can be subjected to differential treatment. Here, family-based resources are associated with a positive affect and treated by default as valuable heritage assets. In contrast, non-family resources are associated with a negative affect and viewed as commodities, regardless of the actual value-creating potential of these resources for the firm. This systematic pattern of differential treatment of two resource categories, or BB (Chua, Chrisman, Steier, \& Rau, 2012; Verbeke \& Kano, 2012), is expressed in a unique set of affect-based decision rules and routines in family firms that are dysfunctional and restrict the firm's access to - and efficient usage of - requisite resources. As such, BB has three main features. It is the product of family-based asset specificity; it represents a unique expression of bounded rationality, whereby an affect bias clouds decision makers' judgment and preferences when selecting decision rules and routines; and it can act as a trigger of bounded reliability in some family firms, e.g., when technically incompetent family managers, through being appointed to high office, can obstruct competent non-family managers, who may in turn become demotivated and unreliable, 
and ultimately leave the firm. While not all family firms are bifurcation biased, they are by default more susceptible to BB than their non-family counterparts, and this contributes to explain their overall, low rates of survival (Kano \& Verbeke, 2018).

Mainstream TCE acknowledges a feedback effect between the macro-environment and the individual (Williamson, 1996), but its core focus is on transaction-related efficiency. In contrast, the ways in which individual attributes can affect the firm's interactions with macrolevel shift parameters are not a typical subject of study in TCE. Below, we do address such interactions in the family firm context. More specifically, we explain how family firms can use corporate diplomacy processes to economize on bifurcation bias.

\section{CORPORATE DIPLOMACY AS AN ECONOMIZING STRATEGY IN FAMILY FIRMS}

\section{Corporate diplomacy and social capital}

Corporate diplomacy can be defined in managerial terms as "an attempt to manage systematically and professionally the business environment in such a way as to ensure that business is done smoothly" (Steger, 2003, p. 18). The concept originated in the field of international relations, and is fairly new to management research, where it has been used predominantly to explain responses by firms to political and social forces in the global economy (Westermann-Behaylo, Rehbein, \& Fort, 2013). Management scholars who study corporate diplomacy have identified a range of objectives of corporate diplomacy processes, including adaptation to volatile and fragmented environments, meeting expectations of diverse stakeholders (Steger, 2003), dealing with exogenous crises (Saner, Yiu, \& Søndergaard, 2000), increasing legitimacy (Ordeix-Rigo \& Duarte, 2009), and cultivating a long-term organizational mindset (Henisz, 2014).

At the core of corporate diplomacy, and often coinciding with its definition, is the management of relationships with stakeholders (Westermann-Behaylo et al., 2015), which supports a firm's 'license to operate'. Ordeix-Rigo and Duarte (2009, p. 557) argue that: 
"corporate diplomacy is a way to strengthen the network of stakeholder relationships for a company and thus a valid stakeholder management strategy". These stakeholder relationships are embedded in, and facilitated by, inter-personal relationships, which link organizations. Many of the components of corporate diplomacy, such as dialogue, bidirectional processes, participatory decision-making, and engagement with society, can ultimately be viewed as process elements strengthening the firm's social capital. In business firms, social capital in the form of network ties, functions as a governance mechanism facilitating economic transactions (cf. Nahapiet \& Ghoshal, 1998: p. 243). Henisz (2016) and Saner et al. (2000), though not establishing a link with the social capital construct, emphasize that corporate diplomacy is about developing relationships outside of the firm, at multiple levels, as a means to establish mutual understanding.

Family firms supposedly command unique social capital (as compared with nonfamily firms) to support their economic transactions (Chrisman et al., 2011). The family, because of its clear boundaries, and because it is a locus for repeated exchange, facilitates the development of social capital (Coleman, 1988). Family firms benefit from access to kinship networks and typically also maintain historical and social ties with their communities; these ties, as well as flexibility in building long-term reciprocal relationships with stakeholders, are argued to provide family firms with social capital advantages over their nonfamily counterparts, whose relationships are constrained by formal procedures and structures, as well as short-term shareholder-driven considerations (Acquaah, 2012).

Sociologists distinguish between bonding social capital and bridging social capital. Bonding social capital signifies 'closure', and defines boundaries separating the members of a group, who share specific collective goods, from non-members (Adler \& Kwon, 2002; Putnam, 2000). Bridging social capital refers to ties among otherwise unconnected people and groups (Gedajlovic \& Carney, 2010), which support the circulation of ideas across different social 
contexts (Adler \& Kwon, 2002; Burt, 2004), and provide access to financial and human resources (Kang, 2003; Putnam, 2000). The challenge for family firms is to combine their unique bonding social capital in the realm of family ties (Gedajlovic \& Carney, 2010), with bonding social capital within the firm, but beyond family ties, and with bridging social capital.

As suggested above, social capital and corporate diplomacy processes can be given a TCE interpretation. The essence of social capital as a governance mechanism, resides in the ties connecting individuals and groups. These ties can support the economic efficiency of transactions, to the extent that they reduce information asymmetries and reliability challenges. By deploying corporate diplomacy processes, family firms can strengthen their foundational bonding social capital advantage in the realm of family ties, and extend it to non-family ties inside the firm, and to bridging social capital with external stakeholders, thereby reducing BB and fostering longevity. In the spirit of Ordeix-Rigo and Duarte (2009), a distinction can be made among three process steps (focused here on bridging social capital):

1. Familiarity: Here, the firm aims to become more familiar with outside stakeholders, and to familiarize these stakeholders with the firm.

2. Acceptance: The aim of this step is to align corporate values - and achieve recognition of a fundamental similarity - with stakeholder values, so that the stakeholders would view the firm as a value-creating party.

3. Engagement: Firms strive to co-create value with - and for - the stakeholders.

Family firms can implement these steps to economize on BB so as to both effectively respond to macro-level shift parameters and to sustain efficient governance at the firm level. Further, family firms can utilize corporate diplomacy steps to transmit economizing practices to subsequent generations, in order to support longevity. First, externally, in the realm of bridging 
social capital, family firms must have a keen awareness of their environment and stakeholders; accept stakeholders outside of the immediate kinship circle as relevant; and engage with them meaningfully so as to mitigate external shocks. Second, internally, and more in the realm of bonding social capital, founding families must familiarize themselves with non-family assets (both human and non-human), accept those assets as non-commodity, and engage with them in a meaningful way so as to achieve efficiency and create long-lasting value for the firm. Third, again in the realm of bonding social capital, but related to family ties, cross-generational transmission of efficient practices and access to the firm's entire reservoir of social capital, follows the same processes, whereby future generations of family are purposefully socialized to achieve familiarity and acceptance, and reciprocal engagement between generations (whether structured or unstructured).

The above tripod of corporate diplomacy process-steps leading to augmented social capital, complements the conventional TCE arsenal of economizing tools that seldom focuses on process-related antecedents to effective governance mechanisms. In the following sections, we describe how family firms can apply the three processes of corporate diplomacy to sustain longevity. Our arguments are summarized in Table 1.

(Insert Table 1about here)

\section{Corporate diplomacy: Macro level and outside actors}

Family firm scholars have identified the ability to manage stakeholder relationships by using the family's social capital as one of the explanations for the long-term survival of some family firms (Sharma, 2008; Miller \& Le-Breton Miller, 2005; Ward, 2004). Although the immediate advantage of family firms is the social capital residing in the family acting as a governance tool, the family's set of extended relationships can also support economic transactions in ways not available to a non-family firm (Carr, Cole, Ring, \& Blettner, 2011). For example, relatives that 
do not work in the firm can act as bridges, linking family managers with distant social groups, such as, for example, an NGO that holds adversarial views of the firm and would otherwise be closed to the idea of constructively communicating with it.

Family-based social ties are unique in that they become established over a long term and permeate both the family and the firm domains (Habbershon, Williams, \& MacMillan, 2003). Family-based social ties complement conventional contractual mechanisms for economizing on bounded reliability in contexts where institutional environments are weak or uncertain. Due to their complexity and embeddedness, these ties are difficult for competitors to imitate (Stadler, Mayer, Hautz, \& Matzler, 2018), and the continuity of succession enables family firms to maintain and exploit their social networks more effectively and over the long run (Le BretonMiller \& Miller, 2006; Sirmon \& Hitt, 2003). The shorter managerial tenures and performance horizons of non-family firms make it difficult to develop and maintain stakeholder relationships that help manage macro-level shifts (Henisz, 2016).

Family firms start with a governance advantage, because they can rely on family-based social capital, amassed over a long period of time (Gedajlovic \& Carney, 2010). However, family firms are also particularly vulnerable to the negative effects of 'social closure', that is, circumstances where a firm prioritizes transactions with stakeholders based on pre-existing network ties, without evaluating real-world alternatives (Ostrom, 2000; Gargiulo \& Benassi, 2000). Further, family firms' social ties are often local and restricted to a selected group of 'trusted' individuals and organizations (Berrone, Cruz, Gomez-Mejia, \& Larraza-Kintana, 2010; Stadler et al., 2018). These ties limit the firm's growth, as it becomes challenging for internationally or functionally diversified family firms to continuously rely on a limited spectrum of network ties for complex transactions (Arregle et al., 2007). The challenge arises when family firms become entrenched in 'special' relationships, to the exclusion of other relevant partners - 
e.g., family firms may be slow to change trusted suppliers even when there are performance problems (Uhlaner, van Goor-Balk, \& Masurel, 2004), or to accept non-kin/non-family stakeholders as potentially reliable (Reuber, 2016). These issues can be characterized as expressions of $\mathrm{BB}$ in the realm of bridging social capital. Here, the three steps of corporate diplomacy facilitate economizing on $\mathrm{BB}$.

Reciprocal familiarization. This first step of corporate diplomacy entails that the family firm should develop familiarity with features and capabilities of a broad range of stakeholders, both current and potential, beyond those that are already linked to the family via existing social capital. Contextual awareness, resulting from the constant scanning of the macro environment and associated players, is a critical ingredient of familiarization. Macro-level shift parameters bring with them shifting stakeholder relevance. Family firm managers must identify relevant players in the changing environment, with whom reciprocal links should be established. These actors may include political figures, actors in relevant non-market institutions that can contribute relevant knowledge, as well as commercial intermediaries and potential partners (Kano, 2018). At the same time, the continued relevance of current linkages must be assessed, so as to determine whether present linkages with external actors are advancing or limiting the firm's adaptation to its macro-environment, and whether they maintain their economic value (Seigal, 2007).

The familiarization step is necessarily reciprocal, which means that the firm must also become familiar to a broad range of stakeholders (the market, potential partners and intermediaries, institutional stakeholders, etc.). In the context of a family firm, this includes familiarizing the environment not only with the firm's economic value proposition, but also with the 'family angle'. This includes communicating the family identity (as it relates to the way the business is run) to external stakeholders and providing relevant "family persona cues" (Parmentier, 2011, p. 222). The family can present itself as a guarantor of continuity or a 
guardian of the craft (Micelotta \& Raynard, 2011). For example, locally oriented firms in the hospitality sector frequently focus their external communications on conveying the message that family involvement implies continuity of business and adherence to traditions (Blombäck \& Craig, 2014). Family firms producing luxury goods or, more broadly, substantially differentiated products, may communicate the family's involvement as an indication of a "craft mentality" (Hennart, Majocchi, \& Forlani, 2017, p. 10) and a signal of quality. This communication typically happens through a number of public channels, including company websites, traditional media, social media, published materials, visual cues (Blombäck \& Craig, 2014; Parmentier, 2011), as well as informal communication with stakeholders.

Mutual acceptance. In this second step, family firms seek to become known to outside stakeholders as an attractive, capable and honest partner. Mutual acceptance entails going beyond familiarization, towards recognizing elements of consistency between the firm's value system and that of the surrounding society and its stakeholders.

In terms of gaining acceptance from relevant societal stakeholders, family firms are argued to have a natural advantage over their non-family counterparts. Acceptance can be accomplished through forging a family firm's reputation for honest business dealings, and family firms are known for their preoccupation with having a good reputation in their location of origin, which facilitates the alignment of values between firm and society, instrumental to long term survival (Dyer \& Whetten, 2006; Ordeix-Rigo \& Duarte, 2009). The family's identification with the firm creates strong incentives for developing a reputation for integrity (Berrone et al., 2012). Further, family firms are frequently associated with such qualities as a human touch and authenticity, which contributes to positive business reputation (Westwood, 1997). But the challenge for all firms, family and nonfamily ones, is to accept as legitimate the views of a variety of stakeholders whose claims may become more salient as the result of changing macro- 
level conditions (such as shifts in government regulations), including those with no explicit connections to the family, and those who in earlier periods may have been viewed as fringe stakeholders. The one advantage of family firms in the realm of developing new bridging capital, is that family members can provide continuity in the process of crafting mutual acceptance.

Mellerio, the oldest jewelry producer in the world, developed stakeholder relationships in multiple countries and with different, even adversarial, groups, through personal involvement of its family employees. The mutual acceptance helped the firm, and the family, survive dramatic macro-level shifts, including the French Revolution. Had the firm relied solely on the family's immediate circle of stakeholders, mostly clients in the French Royal Court by the 1780s, it might have suffered the same faith as most Court members, that is, death by guillotine. As another example, Asian family business groups have a long history of navigating political and industrial change by forging lasting relationships with relevant governments (Gedajlovic \& Carney, 2010). Mutual engagement. At this stage, the family firm establishes itself as an attractive business partner and valuable community member. The family firm is able to influence society, and in turn willing to adapt and change in order to advance relevant interests of the community and its diverse members. Long-term commercial success is contingent on engagement with a variety of outside actors who can subsequently advance the firm's business. At the mutual engagement stage, the family firm solidifies partnerships with outside actors who can advance its business interests; these ties can facilitate long-term inter-firm cooperation and be associated with credible mutual commitments, which involve bilateral asset-specific investment by partners, referred to in TCE as a 'hostage exchange'. As was the case in the acceptance process step, family firm members can typically provide more continuity in the engagement process than nonfamily firms. Zara, IKEA, and H\&M are known for long-lasting and stable relationships with a variety of international suppliers (Pongelli, Calabrò, \& Basco, 2018). Specifically, IKEA's 
decades-long relationships with globally dispersed suppliers, have been associated with mutual asset-specific investments: IKEA provides suppliers with significant technological support, and suppliers invest in learning and technological upgrading (Ivarsson \& Alvstam, 2011).

It has been repeatedly argued that the family character of the business positively impacts family firms' relationships with various constituencies (Uhlaner et al., 2004), and that family firms have a natural advantage at forging committed, lasting ties with outside stakeholders. Family firms' extensive engagement with external parties has been empirically shown to improve performance by filling potential gaps in the political, social and economic infrastructures of external markets where the firms operate (Miller, Lee, Chang, \& Le Breton-Miller, 2009).

The direct involvement of the family and senior family firm leaders in philanthropy and political activities supports the firm's continued engagement with different groups of stakeholders, and signals the firm's long-term commitment to the community loci where it operates - consider, for example, the Du Pont family's long-standing involvement in local politics (Chandler \& Salsbury, 1971). As stated by Pearson et al. (2008, p. 961): “The family’s existing structure and long-standing internal relationships help build the stability necessary to generate social capital. Families bring with them into the economic decisions associated with a business both a shared history over time and relatively durable, lasting relationships". The continuity of the family as a social group supports the continuity of relationships between the firm and stakeholders. Family managers' longer tenures make them more appealing interlocutors for stakeholders that wish to establish a dialogue with the business, and pre-existing family ties and family history can support mutual engagement, for example via shared values or symbols. Like the family firm itself, community stakeholders may be on the receiving end of positive and negative spillovers from macro-level events (Basdeo, Smith, Grimm, Rindova, \& Derf, 2006; 
Rindova, Williamson, Petkova, \& Sever, 2005; Zavyalova, Pfarrer, Reger, \& Shapiro, 2012). Prior, long-term engagement in developing bridging capital can thus determine whether the community opportunistically turns against a family (and its businesses) and tries to benefit from exogenous shocks, e.g., by stealing property, or, on the contrary, helps the firm withstand shocks (Gao et al., 2017). The importance of long-term community engagement helps explain family firms' heightened emphasis on ethical practices and philanthropic behavior (Campopiano \& De Massis, 2015; Campopiano, De Massis, \& Chirico, 2014).

This strategy is actively pursued by Frescobaldi, an Italian family firm that has been producing wine for over 700 years. During WWII, Frescobaldis' most important wine production site was first occupied, then bombed, by the Nazis, causing significant economic loss. The family escaped, helped by the local population, and by a large network of stakeholders, including the family firm's employees. A contemporary example of the family's corporate diplomacy activities is its involvement in producing Gorgona - a wine made by prisoners on the island of Gorgona, a penitentiary, through a partnership with local authorities. The Frescobaldi family organized and financed the project, which it thinks has a great symbolic and social value, and which has been widely praised in the industry (Wislocki, 2017).

To summarize, achieving longevity requires continuous adaptation to macro-level shift parameters, which, in turn, is contingent on co-opting a broad range of stakeholders, beyond those directly linked to the family. Family firms hold a foundational advantage in deploying bonding social capital in the realm of family ties, but they must consciously employ corporate diplomacy processes to develop bridging capital, which is only possible if they are unimpeded by BB. In the absence of BB, the possibility of long-term continuity in the acceptance and engagement steps through utilizing family members and reputational resources, gives family firms an edge over nonfamily ones. 


\section{Corporate diplomacy and BB: Firm level}

Distinct features ascribed to family firms often stem from the bonding social capital that links family members. Bonding social capital as a governance mechanism promotes commitment and conflict resolution, and facilitates acquiring valuable resources (Portes, 1998). Non-family employees, by definition, are not part of the closed social group that is the family (Adler \& Kwon, 2002). The family's bonding social capital can have an exclusionary effect, leading to, and reinforcing, BB. Family firms thus have a unique governance mechanism at their disposal in the form of family-related bonding social capital, but BB may prevent proper usage thereof in business transactions. Dysfunctional family ties might even prevent further development of bonding social capital that would extend beyond family ties. Here again, corporate diplomacy process steps can be deployed to economize on BB at the firm level.

Reciprocal familiarization. Family firm insiders are known to possess a high level of familiarity with each other's conduct and expertise; this familiarity arises from family relationships, or the bonding social capital of the family (Fama \& Jensen, 1983; Lubatkin, Durand, \& Ling, 2007), and is reinforced by early socialization of family members into the company (Lee, Lim, \& Lim, 2003). Non-family managers do not benefit from the prolonged socialization of family members. As a result, non-family employees do not possess the same degree of idiosyncratic knowledge about the company as family insiders, nor does the company know them to the same extent (Verbeke \& Kano, 2012).

Improving the founding family's understanding of non-family employees' conduct and expertise, and transferring idiosyncratic knowledge about the firm to non-family managers, are the objectives of the familiarization stage. Mutual familiarization can be achieved through both formal and informal channels. Family firms can share information through forums and meetings, and provide employees with access to documentation/archives that contain information about the 
firm. Non-family employees should be socialized into the routines, shared stories, and symbols of the firm. Notably, most of the Henokiens, a club of family firms that have survived for over 200 years, report using specific practices, such as family meetings where non-family employees are invited, and celebrations of specific moments of the firm's history, in order to inform nonfamily employees about the firm, its history, its values, and to get to know non-family employees through repeated social interactions.

Mutual acceptance. At the acceptance stage, the fundamental similarity in the value systems of the family, the firm and non-family employees is recognized, and these values are enacted through the firm's strategy. Acceptance, however, may be more challenging than familiarizing for the founding family. "Amoral familism” (Banfield, 1958, p. 83), defined as dysfunctional distrust of outsiders, is a well-documented expression of BB (Dyer, 2006; Verbeke \& Kano, 2012). It manifests itself as a refusal to accept non-family employees as valid end equal contributors to the firm. The lack of acceptance can damage relationships and create a "vicious cycle of increasing bounded reliability" (Verbeke \& Kano, 2012, p. 1193) between family and non-family employees.

Acceptance of outsiders is reflected in the willingness to share power and legitimacy e.g., allowing a non-family CEO to make and implement strategic decisions - which is "one of the hardest issues for family firms to come to terms with" (Cadbury, 2000, p. 8). Sir Adrian Cadbury, a former chairman of Cadbury Ltd., a third generation, British family-owned confectionary firm, argues that the family shareholders' role is to act as the guardians of values, and to help non-family executives understand the family firm's philosophy. Yet, when it comes to strategic and operational decision-making power, the family must accept that "there should be no doubt where the power to make decisions lies. It is solely with the executives in charge of running the business" (Cadbury, 2000: 24). These executives, in turn, must accept the firm's 
original philosophy and operate accordingly. Even more than with familiarization, mutual acceptance hinges on systemic information exchange (see reciprocal familiarization discussed above), whereby the family provides counsel to assist executives in their task, and the executives keep the family informed.

Acceptance thus means that non-family managers' power to make decisions and the legitimacy of these decisions is accepted without excessive scrutiny by the family. If non-family members do not have the power to structure business transactions according to economizing principles, inefficiencies will ensue. For example, Peugeot, a French automotive family firm, had non-family CEOs for decades, but strategies proposed by these executives (e.g., relocation of production and cooperative entry into foreign markets) often conflicted with the family's pursuit of non-economic goals, such as maintaining a high share of production in France in spite of high costs, and avoiding alliances to retain full operational control of the firm. The lack of mutual acceptance between the family and its CEOs ultimately eroded the legitimacy of the non-family executives, resulting not only in a high turnover of senior managers, but also in increasingly inefficient operations, declining sales and mounting debt. Peugeot's fortunes changed when the family, facing a brush with bankruptcy, shifted its stance and began deferring strategic decisions to external CEOs. ${ }^{3}$ Under Carlos Tavares, a non-family CEO in charge since 2014, Peugeot went through a vigorous recovery, punctuated by a reversal of previous strategies linked to preferences of the family: the firm forged new alliances and increased the role of external investors to support international expansion (Dupont-Calbo \& Amiot, 2017; Fainsilber, 2014).

\footnotetext{
${ }^{3}$ The change in stance towards acceptance of non-family executives was possible only after a family feud between the two brothers who led the firm at the time was solved, and Thierry Peugeot, the brother deemed responsible for hindering alliances and undermining external CEOs' decisions, was pushed out of the firm (Dupont-Calbo \& Amiot, 2017). Since then, the family and executives have been mutually accepting their respective authority and decisions.
} 
Mutual engagement. As far as the interaction between the family and nonfamily top managers is concerned, it is difficult to disentangle mutual acceptance and engagement. These two process steps almost coincide, in the sense that accepting a senior executive's perspective on the family business goes hand in hand with empowering this executive to conduct business transactions as she or he sees fit. But for lower-level employees, mutual engagement is a clearly distinct process step, going much further than acceptance.

At the individual level, engagement implies the cognitive and emotional investment of an individual into his or her work (Kahn, 1990). Barrick, Thurgood, Smith, and Courtright (2015) adapted Kahn's conception of engagement to a collective organizational level, and defined organizational engagement as the shared perception of organizational members' requisite levels of investment and commitment. We build upon this work to conceptualize a family firm's engagement with its non-family employees as the shared perception among family members of the family's level of investment in, and commitment to, non-family members inside the firm. The desired outcome of mutual engagement in a family business is firm-wide commitment to the purpose and values of the firm (whereby non-family employees are fully co-opted into the firm), and a reciprocal endorsement of the firm as an attractive employer by the non-family employees (Ordeix-Rigo \& Duarte, 2009). Mutual engagement supports longevity in that it results in longer employee tenure/low turnover, long-term collaborations, and ultimately improved firm-level performance outcomes (Barrick et al., 2015; Kahn, 1990).

In practical terms, mutual engagement implies that non-family employees are invested in the vision, mission, and value of the firm, and the family is committed to non-family employees as long-term members of the team. This commitment can be reinforced informally through socialization, and formally through the sharing of both rewards and liabilities among parties (both financial and non-financial), and through merit-based (rather than particularistic) human 
resources practices, particularly in the realm of rewards and incentives. Merit-based incentives stimulate mutual engagement by signalling to non-family employees that the family values their contribution. Equity sharing is fairly uncommon in family firms due to families' reluctance to dilute ownership, but some successful, long-lived family firms, such as Du Pont, have offered employees shares in the business (Chandler \& Salsbury, 1971), to solidify mutual commitments.

Family businesses are naturally well positioned to foster mutual engagement within the firm, thereby augmenting their bonding social capital beyond family ties. Yet, empirical evidence suggests that family members have a significantly greater level of engagement in their firms than non-family employees (Ramos, Man, Mustafa, \& Ng, 2014). The bonding social capital related to family ties, thus appears more robust than that related to ties with non-family employees. The most successful family firms therefore make it a priority to meaningfully engage with, and demonstrate commitment to, non-family talent, and receive reciprocal commitment. Frescobaldi introduced engagement practices as early as in the $17^{\text {th }}$ century, making Francesco Mazinghi, a non-family executive, a minority shareholder in the firm (Frescobaldi, Solinas, \& Tosi, 2004). The youngest generation of managers believes that the company's success over the past fifty years is due largely to the fact that professional managers and employees are made "feel that it's their company" (interview with Matteo Frescobaldi, 2017). Matteo Frescobaldi clarified this point as follows:

"I cannot think of any situation where the family has what employees do not have. We have the same discount for the products as employees. If we want to take some wine, we have to buy it. Our properties are for company use, and no family member can use the estate for personal purposes. Managers of the estates are not family members, but they feel like the estate is their own."

Merck, a German family firm producing drugs and chemicals since the 17th century, facilitates engagement by ensuring that all the executives who are members of its Board share the 
same risks and advantages of family members by becoming shareholders, but also accept unlimited personal liability for up to five years after retirement. Jon Baumhauer, Chairman of Merck's Executive Board and the $11^{\text {th }}$ generation family member, affirmed in an interview that "...it is important for all member of the Executive Board, even non-shareholders, to share both the risks and rewards of the owners" (quoted in Leleux \& Glemser, 2011, p. 12).

\section{Corporate diplomacy across levels: Cascading effects}

Corporate diplomacy results in augmented bridging social capital (ties with outsiders, including stakeholders in the macro-environment) and bonding social capital (ties inside the firm). These various types of social capital, as governance mechanisms, interact in a 'cascading' way: The firm's corporate diplomacy actions targeted toward economizing on BB in either sphere will create positive impacts across levels (firm versus macro-environment), domains (economic, social, political and institutional) and time periods. For example, the reputation of a firm as an attractive employer (bonding capital outcome of corporate diplomacy at the firm level) may trigger a broader positive reputation in the community and create goodwill with regulators (augmented bridging social capital). Here, the reputation of Mellerio and Frescobaldi as reliable business partners and fair employers, supported broader stakeholder relationships, helping them survive, especially in times of extreme macro-level volatility, such as, respectively, the French Revolution and World War II. Similarly, a firm's reputation in the business community, i.e., its reputation as an attractive business partner (reflecting bridging social capital in the business contracting sphere) reinforces the public perception of the firm as a desirable employer, thus augmenting bridging social capital with stakeholders in the macro-environment.

On the negative side, BB, whereby non-family employees are treated unfairly as compared to family members (reducing bonding social capital), will send negative signals to 
external stakeholders (thereby reducing bridging social capital). In turn, failing to accept particular external stakeholders (reducing bridging social capital), may cause hostility by nonfamily employees, if the latter have a shared identity and common values with such external stakeholders (thereby reducing bonding social capital outside of the family ties). A firm that is disengaged from the social context in which it operates (reduced bridging social capital) may also find it hard to attract talent (reduced potential for bonding social capital), thereby igniting additional bounded rationality and reliability challenges.

Importantly, positive cascading effects can sustain the firm's overall social capital over longer periods of time, but corporate diplomacy efforts must be maintained in order to have a lasting impact. The Fiat Group, an Italian carmaker owned by the Agnelli family, offers an illustration. The history of Fiat was punctuated by successful corporate diplomacy efforts both internally and externally. Internally, the Agnelli family identified and hired talented non-family managers, accepted the value they brought to the firm, and engaged with them fully. Externally, the family navigated macro-level contextual changes successfully by engaging with stakeholders who drove such changes, for example moving from being one of the leading suppliers of military equipment for the Fascist regime to becoming a key recipient of the US-funded Marshall Plan aid in Italy, and the largest industrial firm of the post-war economic miracle. When, however, the ailing Giovanni Agnelli resisted adapting business deals he personally negotiated with authoritarian regimes (e.g., in Spain, the USSR, and Yugoslavia) to the new political context of the 1990s, Fiat entered a dramatic period of decline. Fiat's struggles were exacerbated by Agnelli's insistence on hiring 'old guard' managers, with whom he had personal ties. The firm turned around after Agnelli's death, under the leadership of Sergio Marchionne, a non-family CEO (Volpato, 2008; Tagliabue, 2003). 


\section{TRANSGENERATIONAL DISSEMINATION OF GOVERNANCE PRACTICES:}

\section{APPLICATION OF CORPORATE DIPLOMACY PROCESSES}

Corporate diplomacy efforts offer family firms an opportunity to strengthen their overall social capital as a governance mechanism. However, the challenge is to maintain for the next generation the resulting, improved ties inside the firm with non-family members, as well as stronger ties with outside business stakeholders, and with stakeholders at the macro-level. To achieve longevity, each subsequent generation of family members in the firm must be able to access and rely upon the existing pool of network ties functioning as a governance tool to support economic transactions (Hall, Melin, \& Nordqvist, 2001; Lumpkin, Martin \& Vaughn, 2008). Guaranteeing access to - and ability to rely on - the entirety of extant network ties can be facilitated through the three corporate diplomacy steps, which in this case aim to (a) improve the family ties among different generations, and (b) involve the younger generation in the broader pool of ties held with multiple stakeholders.

Reciprocal familiarization. The current generation must ensure that successive generations in the family become familiar with the business, while the current generation is familiar with the next generation's set of competencies. This occurs through cross-generational communication of stories, traditions, rituals and relational laws (Lumpkin et al., 2008). Formal documents outlining the firm's set of values, organization and governance principles - e.g., a family constitution or a family protocol - present a structured way to share relevant information across generations. The current generation can invite upcoming generations to participate in family meetings and events, promote the family archives, share family-specific publications, and organize a forum - e.g., a family intranet - where information about the family and the firm is shared. Cohabitation/co-location, where multiple generations of family involved in the business reside in close proximity, is an effective way to achieve mutual familiarization, and is frequently 
practiced by old family firms, particularly those involved in agriculture - for example, the Frescobaldi maintain a family estate that serves as corporate headquarters but also houses three generations of family employees; all family members joining the business are expected to relocate to the residence.

Mutual acceptance. At this stage, younger generations accept their role in the family, and the firm's value system. In turn, older generations accept potential value and contribution brought by the younger generation. Successive generations need to accept strategic decisions made by current and prior leadership, which may be difficult particularly if decisions are controversial and/or involve shedding assets that hold an emotional value for the family (Salvato $\&$ Melin, 2008). Such mutual acceptance hinges on open communication (discussed in the familiarization process stage above) and is frequently achieved through informal socialization, whereby younger generations are groomed practically from birth. However, many successful family firms run formal mentorship programs, where upcoming generations are educated on the realities of the business in a practical setting, including especially the existing network ties maintained by the firm.

A more formal approach to cross-generational mutual acceptance implies that family protocols are treated as agreements, whereby different generations of family are expected to sign a document outlining mutually agreed upon values. This practice, followed by a number of Henokiens, ensures that governance principles are aligned with aspirations and ideas of younger generations (Tàpies \& Fernández Moya, 2012).

Finally, mutual acceptance assumes that subsequent generations must have the freedom to adapt governance mechanisms, including the firm's reservoir of social ties, to match their skills and capabilities, and relevant contextual changes (i.e., macro-level shift parameters, business trends, competitive pressures, etc.). This means that knowledge on an agreed upon, core set of 
values and practices as well as network relationships, must leave sufficient room to incorporate unique values and preferences for new practices and network ties of the next generation (cf. Tàpies \& Fernández Moya, 2012).

Mutual engagement. Here, older generations engage younger generations and empower them to contribute to the firm, for example, by suggesting new social ties to be created and taking responsibility for new products or ventures. These ideas can be solicited formally, through channels that allow for an assessment and implementation of suggestions that arise across generations. Some family firms engage new generations from an early age through internships, and develop formal career plans for family members who wish to join the firm. Crossgenerational initiatives, such as technical and professional forums, further co-opt younger generations of family into the firm. Finally, different generations can be asked to work jointly on large projects with important social capital implications - for example, managing a joint venture (Salvato \& Melin, 2008) or leading a corporate restructuring (Chandler \& Salsbury, 1971).

Merck provides rich examples of how corporate diplomacy processes are utilized to transmit core practices across generations. Presently 130 of Merck's 200 family members are shareholders of the firm. Merck Magna Carta, a document dating back to the 1800s, formally outlines the firm's values, organization, and governance principles. The document serves as a reference point for family members who want to learn about the business. A family magazine and a family-specific intranet facilitate familiarization by keeping the family informed and updated on the activities of the firm. Further, family members enter formal business mentorship programs from the age of 15 , and are introduced to each other, to older generations, and to the broader network through targeted events, such as joint non-business trips, which support mutual acceptance. Finally, engagement is cultivated by ensuring the continuous involvement of family 
members in the business, encouraging participation in the firm's multiple internship programs from a young age, and the exchange of written opinions and ideas through the family intranet and internal documents and memos; ideas are also exchanged across generations and branches of the family at annual meetings. The family organizes technical events aimed at discussing matters related to accounting, scientific research, as well as governance of the firm, and trips visiting foreign subsidiaries. The Chairman of the Family Board has stated that he explicitly welcomes new ideas from younger family members. Employment options are open to family members who have suitable qualifications. However, family applicants are subjected to clear, transparent, meritocratic criteria and a formal interview process carried out by non-family employees, thus strengthening bonding social capital. Upon acceptance, family members discuss a career development plan with senior managers. This process ensures that their ambitions and ideas are formally screened, but also given serious consideration (Leleux \& Glemser, 2011).

\section{CONCLUSIONS, CONTRIBUTIONS AND DIRECTIONS FOR FUTURE RESEARCH}

In this study, we have addressed the family firm longevity paradox, that is, the extreme variation in the lifespan of family firms. A small set of family businesses has outlived all other types of firms, yet many family firms underperform and die before third trans-generational succession. We have argued that there are two related reasons for this duality, highlighting necessary conditions for longevity. First, family firms that exhibit exceptional longevity have been able to overcome economizing challenges brought about by bifurcation bias, both in their business transactions and broader transactions with the macro-level environment. Second, these successful economizing practices were effectively transmitted across generations. The three process steps of corporate diplomacy, namely familiarization, acceptance, and engagement, facilitate successful economizing practices and the transmission thereof. These corporate diplomacy steps lead to 
augmented bonding and bridging social capital, i.e., ties that are a key governance mechanism in support of business and broader transactions.

Family firms have an intrinsic governance advantage in terms of their bonding social capital, to the extent that this involves family ties. Yet, relying on family-based social capital creates the danger of insularity, thereby negatively affecting the creation of bonding social capital beyond family ties, and the crafting of bridging social capital with outside stakeholders. Family businesses achieving longevity are those firms that have been able to overcome BB and have engaged in corporate diplomacy efforts to augment bonding social capital (ties with nonfamily members), and bridging social capital (ties with outside stakeholders, including those operating in the macro-environment). In addition, corporate diplomacy efforts deployed to improve bonding social capital in the realm of ties among successive family generations are critical to the intergenerational transmission of governance mechanisms, including especially the family firm's overall reservoir of network ties. This, we have argued, contributes to explaining the longevity paradox of family firms: Long-lived family businesses are those able to complement intrinsic governance strengths in the realm of family-based ties, with corporate diplomacy processes that augment the firm's broader bonding and bridging social capital, in support of efficient transactions.

Our contribution is threefold. First, we build upon prior studies (Gedajlovic \& Carney, 2010; Memili et al., 2011; Pollak, 1985; Verbeke \& Kano, 2010, 2012) to provide a TCE-based explanation of the family firm longevity paradox, with the capacity to predict when firms are more likely to sustain family governance over several generations. Prior TCE-based studies dealt primarily with the uniqueness of family firm's governance choices, but did not attempt to explain longevity, nor has the concept of BB been linked to longevity. Our augmented TCE-based model helps explain not only why some family firms achieve exceptional longevity (a phenomenon 
discussed in extant literature, e.g., from the stewardship perspective), but also why other family firms do not, thus adding an actionable, predictive dimension to the extant discussion of family firm longevity.

Second, we extend prior work on BB by identifying the specific mechanisms through which firms achieve BB economizing. Here, we adopt corporate diplomacy as a framework to discuss the process-related practices that augment social capital as a governance mechanism, thereby supporting efficient transactions and longevity. Corporate diplomacy thinking is fairly underutilized in management studies at present, but we demonstrate how this process-oriented approach can be used for studying how social capital is created.

Third, we include in our analysis the interplay between the firm and its macroenvironment. While TCE acknowledges the interaction between the firm and its environment, it typically does not address process-related mechanisms that managers employ to improve and augment network ties in response to changes in macro-level shift conditions, in order to support efficient transactions. We extend TCE-based analysis of the family firm by predicting longevity, inter alia as a function of the firm's sustained efforts to augment its bridging social capital and to remain aligned with macro-level shift conditions.

Our study yields actionable implications for family firm leaders. We offer a road map for economizing on BB, and augmenting social capital through corporate diplomacy. We provide illustrations of economizing practices employed in some of the world's oldest and most successful family firms. We also outline distinct, process-related steps for successful management practices and network ties to be transmitted across generations, so as to promote functional governance for the long term.

\section{Limitations}


Studying high longevity could in principle involve a two-pronged analysis: First, identifying instances where negative effects of ill-adapted governance could reasonably have been predicted ex ante, and where as a result, governance mechanisms, especially in the form of network ties, were altered anticipatively by long-lived firms, so as to avoid these negative effects from materializing. Second, analyzing processes of correcting ex post ill-adapted governance, inter alia as a response to changes in the macro-environmental context. Our analysis, though leaving room for the latter approach, has focused primarily on the former, i.e., on preventive and anticipative governance practices, rather than on corrective ones. Our analysis could therefore be criticized for being limited to linking managerial practices (interpreted as having been well-designed anticipatively) with the outcome of longevity, without much focus on when, and how, any (and possibly many) governance failures led to ex post governance corrections, particularly changes in the fabric of network ties commanded by the firm.

It should also be noted that long-lived family firms represent the tail end of a distribution - that is, they remain exceptional cases. It is useful to theorize and describe how these firms achieve longevity, but there are limits to the extent to which these practices are transferable to the average firm. Still, economizing, efficiency-enhancing practices that augment social capital are worth noting and implementing.

\section{Directions for future research}

Future studies can operationalize our model linking economizing mechanisms in the realm of governance and longevity. Exploratory research - e.g., historical case analyses - could be conducted to compare governance in high-longevity family firms and in firms that failed to survive as family businesses, thereby mitigating survivor bias in research. We hope that our analysis, which has introduced corporate diplomacy thinking in the context of family firm 
governance, can contribute to a new research agenda on survival and longevity, involving both family business and strategy scholars.

\section{REFERENCES}

Acquaah, M. (2012). Social networking relationships, firm-specific managerial experience and firm performance in a transition economy: A comparative analysis of family owned and nonfamily firms. Strategic Management Journal, 33(10), 1215-1228.

Adler, P. S., \& Kwon, S. W. (2002). Social capital: Prospects for a new concept. Academy of Management Review, 27(1), 17-40.

Arregle, J. L., Hitt, M. A., Sirmon, D. G., \& Very, P. (2007). The development of organizational social capital: Attributes of family firms. Journal of Management Studies, 44(1), 73-95.

Banfield, E. C. (1958). The moral basis of a backward society. New York: Free Press.

Barrick, M. R., Thurgood, G. R., Smith, T. A., \& Courtright, S. H. (2015). Collective organizational engagement: Linking motivational antecedents, strategic implementation, and firm performance. Academy of Management Journal, 58(1), 111-135.

Basdeo, D. K., Smith, K. G., Grimm, C. M., Rindova, V. P., \& Derfus, P. J. (2006). The impact of market actions on firm reputation. Strategic Management Journal, 27(12), 1205-1219.

Bennedsen, M., \& Foss, N. (2015). Family assets and liabilities in the innovation process. California Management Review, 58(1), 65-81.

Bennedsen, M., \& Henry, B. (2016). Hénokiens: The Families and Firms Who Made History. INSEAD. Retrieved from: http://www.henokiens.com/userfiles/file/The_Henokiens_Case_Introduction_\&_Conclusion.pdf

Berrone, P., Cruz, C., Gomez-Mejia, L. R., \& Larraza-Kintana, M. (2010). Socioemotional wealth and corporate responses to institutional pressures: Do family-controlled firms pollute less? Administrative Science Quarterly, 55(1), 82-113.

Bertrand, M., \& Schoar, A. (2006). The role of family in family firms. Journal of Economic Perspectives, 20(2), 73-96.

Blombäck, A., \& Craig, J. (2014). Marketing from a family business perspective. In Melin, L., Nordqvist, M., \& Sharma, P. (Eds.), The SAGE handbook of family business (pp. 423-441). London: SAGE Publications Ltd.

Burt, R. S. (2004). Structural holes and good ideas. American journal of sociology, 110(2), 349399. 
Cadbury, S. A. (2000). Family firms and their governance: Creating tomorrow's company from today's. London: Egon Zehnder International.

Campopiano, G., \& De Massis, A. (2015). Corporate social responsibility reporting: A content analysis in family and non-family firms. Journal of Business Ethics, 129(3), 511-534.

Campopiano, G., De Massis, A., \& Chirico, F. (2014). Firm philanthropy in small-and mediumsized family firms: The effects of family involvement in ownership and management. Family Business Review, 27(3), 244-258.

Carr, J. C., Cole, M. S., Ring, J. K., \& Blettner, D. P. (2011). A measure of variations in internal social capital among family firms. Entrepreneurship Theory and Practice, 35(6), 1207-1227.

Chandler, A. D., \& Salsbury, S. (1971). Pierre S. du Pont and the making of the modern corporation. New York: Harper \& Row.

Chrisman, J.J. (2018). Stewardship Theory: a critical review of its tenets, boundaries, and applications to family firms governance. Mimeo.

Chrisman, J. J., Chua, J. H., \& Steier, L. P. (2011). Resilience of family firms: An introduction. Entrepreneurship Theory and Practice, 35(6), 1107-1119.

Chua, J. H., Chrisman, J. J., Steier, L. P., \& Rau, S. B. (2012). Sources of heterogeneity in family firms: An introduction. Entrepreneurship Theory and Practice, 36(6), 1103-1113.

Coleman, J. S. (1988). Social capital in the creation of human capital. American Journal of Sociology, 94, S95-S120.

Corbetta, G., \& Salvato, C. (2004). Self-serving or self-actualizing? Models of man and agency costs in different types of family firms: A commentary on "comparing the agency costs of family and non-family firms: Conceptual issues and exploratory evidence". Entrepreneurship Theory and Practice, 28(4), 355-362.

Davis, J. H., Schoorman, F. D., \& Donaldson, L. (1997). Toward a stewardship theory of management. Academy of Management Review, 22(1), 20-47.

Dyer, W. G. (2006). Examining the "family effect" on firm performance. Family Business Review, 19(4), 253-273.

Dyer, W. G., \& Whetten, D. A. (2006). Family firms and social responsibility: Preliminary evidence from the S\&P 500. Entrepreneurship Theory and Practice, 30(6), 785-802.

Dupont-Calbo, J. \& Amiot, M. (2017). Tavares L'autre Carlos. Retrieved from: https://www.lesechos.fr/05/05/2017/LesEchosWeekEnd/00075-008-ECWE tavares-1-autrecarlos.htm. 
Fainsilber, D. (2014). Les difficiles relations du patron de PSA avec la famille Peugeot. Retrieved from:

https://www.lesechos.fr/18/02/2014/lesechos.fr/0203324329502_les-difficiles-relations-dupatron-de-psa-avec-la-famille-peugeot.htm.

Fama, E. F., \& Jensen, M. C. (1983). Separation of ownership and control. The journal of Law and Economics, 26(2), 301-325.

Frescobaldi D., Solinas F., \& Tosi P. (2004). I Frescobaldi: Una famiglia fiorentina. Florence: Le lettere.

Gao, C., Zuzul, T., Jones, G., \& Khanna, T. (2017). Overcoming institutional voids: A reputation-based view of long-run survival. Strategic Management Journal, 38(11), 2147-2167.

Gargiulo, M., \& Benassi, M. (2000). Trapped in your own net? Network cohesion, structural holes, and the adaptation of social capital. Organization Science, 11(2), 183-196.

Gedajlovic, E., \& Carney, M. (2010). Markets, hierarchies, and families: Toward a transaction cost theory of the family firm. Entrepreneurship Theory and Practice, 34(6), 1145-1172.

Gómez-Mejía, L. R., Haynes, K. T., Núñez-Nickel, M., Jacobson, K. J., \& Moyano-Fuentes, J. (2007). Socioemotional wealth and business risks in family-controlled firms: Evidence from Spanish olive oil mills. Administrative Science Quarterly, 52(1), 106-137.

Gomez-Mejia, L. R., Makri, M., \& Larraza Kintana, M. (2010). Diversification decisions in family-controlled firms. Journal of Management Studies, 47(2), 223-252.

Habbershon, T. G., Williams, M., \& MacMillan, I. C. (2003). A unified systems perspective of family firm performance. Journal of Business Venturing, 18(4), 451-465.

Hall, A., Melin, L. \& Nordqvist, M. (2001). Entrepreneurship as radical change in the family business: Exploring the role of cultural patterns. Family Business Review, 24(3), 193-208.

Henisz, W. (2014). Corporate diplomacy: Building reputations and relationships with external stakeholders. Sheffield: Greenleaf Publishing.

Hennart, J. F. (1994). The 'comparative institutional' theory of the firm: some implications for corporate strategy. Journal of Management Studies, 31(2), 193-208.

Hennart, J. F., Majocchi, A., \& Forlani, E. 2017. The myth of the stay-at-home family firm: How family-managed SMEs can overcome their internationalization limitations. Journal of International Business Studies, advance online publication August 21. doi:10.1057/s41267-0170091-y.

Hernandez, M. (2012). Toward an understanding of the psychology of stewardship. Academy of Management Review, 37(2), 172-193. 
Ivarsson, I., \& Alvstam, C. G. (2010). Upgrading in global value-chains: A case study of technology-learning among IKEA-suppliers in China and Southeast Asia. Journal of Economic Geography, 11(4), 731-752.

Jaskiewicz, P., Combs, J. G., \& Rau, S. B. (2015). Entrepreneurial legacy: Toward a theory of how some family firms nurture transgenerational entrepreneurship. Journal of Business Venturing, 30(1), 29-49.

Jennings, J. E., Dempsey, D., \& James, A. E. (2018). Bifurcated HR practices in family firms: Insights from the normative-adaptive approach to stepfamilies. Human Resource Management Review, 28(1), 68-82.

Kahn, W. A. (1990). Psychological conditions of personal engagement and disengagement at work. Academy of Management Journal, 33(4), 692-724.

Kang, D.C. (2003). Transactions costs and crony capitalism in East Asia. Comparative Politics, 35(4), 439-458.

Kano, L. (2018). Global value chain governance: A relational perspective. Journal of International Business Studies, 49(6), 684-705.

Kano, L., \& Verbeke, A. (2015). The three faces of bounded reliability: Alfred Chandler and the micro-foundations of management theory. California Management Review, 58(1), 97-122.

Kano, L., \& Verbeke, A. (2018). Family firm internationalization: Heritage assets and the impact of bifurcation bias. Global Strategy Journal, 8(1), 158-183.

Le Breton-Miller, I., \& Miller, D. (2006). Why do some family businesses out-compete? Governance, long-term orientations, and sustainable capability. Entrepreneurship Theory and Practice, 30(6), 731-746.

Le Breton-Miller, I., \& Miller, D. (2011). Commentary: Family firms and the advantage of multitemporality. Entrepreneurship Theory and Practice, 35(6), 1171-1177.

Lee, K. S., Lim, G. H., \& Lim, W. S. (2003). Family business succession: Appropriation risk and choice of successor. Academy of Management Review, 28(4), 657-666.

Leleux, B. F., \& Glemser, A. (2011). The Mercks of Darmstadt: What family can do. IMD Case Studies, IMD 505.

Lubatkin, M. H., Durand, R., \& Ling, Y. (2007). The missing lens in family firm governance theory: A self-other typology of parental altruism. Journal of Business Research, 60(10), 10221029.

Lumpkin, G. T., \& Brigham, K. H. (2011). Long-term orientation and intertemporal choice in family firms. Entrepreneurship Theory and Practice, 35(6), 1149-1169. 
Lumpkin, G. T., Martin, W., \& Vaughn, M. (2008). Family orientation: individual-level influences on family firm outcomes. Family Business Review, 21(2): 127-138.

Memili, E., Chrisman, J. J., \& Chua, J. H. (2011). Transaction costs and outsourcing decisions in small-and medium-sized family firms. Family Business Review, 24(1), 47-61.

Micelotta, E., \& Raynard, M. (2011). Concealing or revealing the family? Corporate brand identity strategies in family firms. Family Business Review, 24(3), 197-216.

Miller, D., \& Le Breton-Miller, I. (2005). Managing for the Long Run: Lessons in Competitive Advantage from Great Family Businesses. Boston, MA: Harvard Business Press.

Miller, D., \& Le Breton-Miller, I. (2006). Family governance and firm performance: Agency, stewardship, and capabilities. Family Business Review, 19(1), 73-87.

Miller, D., Lee, I., Chang, S., \& Le Breton-Miller, I. (2009). Filling the institutional void: The social behavior and performance of family vs non-family technology firms in emerging markets. Journal of International Business Studies, 40, 802-818.

Nahapiet, J., \& Ghoshal, S. (1998). Social capital, intellectual capital, and the organizational advantage. Academy of Management Review, 23(2), 242-266.

Ordeix-Rigo, E., \& Duarte, J. (2009). From public diplomacy to corporate diplomacy: Increasing corporation's legitimacy and influence. American Behavioral Scientist, 53(4), 549-564.

Ostrom, E. (2000). Collective action and the evolution of social norms. Journal of Economic Perspectives, 14(3), 137-158.

Parmentier, M. A. (2011). When David met Victoria: Forging a strong family brand. Family Business Review, 24(3), 217-232.

Pearson, A. W., Carr, J. C., \& Shaw, J. C. (2008). Toward a theory of familiness: A social capital perspective. Entrepreneurship theory and practice, 32(6), 949-969.

Pongelli, C., Calabrò, A., \& Basco, R. (2018). Family firms' international make-or-buy decisions: Captive offshoring, offshore outsourcing, and the role of home region focus. Journal of Business Research. doi:10.1016/j.jbusres.2018.02.033.

Pollak, R. A. (1985). A transaction cost approach to families and households. Journal of Economic Literature, 23(2), 581-608.

Portes, A. (1998). Social capital: Its origins and applications in modern sociology. Annual Review of Sociology, 24, 1-24.

Putnam, R.D. (2000) Bowling alone. New York: Simon and Schuster. 
Ramos, H. M., Man, T. W. Y., Mustafa, M., \& Ng, Z. Z. (2014). Psychological ownership in small family firms: Family and non-family employees' work attitudes and behaviours. Journal of Family Business Strategy, 5(3), 300-311.

Reuber, A. R. (2016). An assemblage-theoretic perspective on the internationalization processes of family firms. Entrepreneurship Theory and Practice, 40(6), 1269-1286.

Rindova, V. P., Williamson, I. O., Petkova, A. P., \& Sever, J. M. (2005). Being good or being known: An empirical examination of the dimensions, antecedents, and consequences of organizational reputation. Academy of Management Journal, 48(6), 1033-1049.

Salvato, C., \& Melin, L. (2008). Creating value across generations in family-controlled businesses: The role of family social capital. Family Business Review, 21(3), 259-276.

Saner, R., Yiu, L., \& Søndergaard, M. (2000). Business diplomacy management: A core competency for global companies. Academy of Management Perspectives, 14(1), 80-92.

Schulze, W. S., Lubatkin, M. H., Dino, R. N., \& Buchholtz, A. K. (2001). Agency relationships in family firms: Theory and evidence. Organization science, 12(2), 99-116.

Seigal, J. (2007). Contingent political capital and international alliances: Evidence from South Korea. Administrative Science Quarterly, 52, 621-666.

Sharma, P. (2008). Commentary: Familiness: Capital stocks and flows between family and business. Entrepreneurship Theory and Practice, 32(6), 971-977.

Sharma, P., \& Manikutty, S. (2005). Strategic divestments in family firms: Role of family structure and community culture. Entrepreneurship Theory and Practice, 29(3), 293-311.

Sirmon, D. G., \& Hitt, M. A. (2003). Managing resources: Linking unique resources, management, and wealth creation in family firms. Entrepreneurship Theory and Practice, 27(4), 339-358.

Stadler, C., Mayer, M. C., Hautz, J., \& Matzler, K. (2018). International and product diversification: Which strategy suits family managers? Global Strategy Journal, 8(1), 184-207.

Stamm, I., \& Lubinski, C. (2011). Crossroads of family business research and firm demography - A critical assessment of family business survival rates. Journal of Family Business Strategy, 2(3), 117-127.

Steger, U. (2003). Corporate diplomacy: The strategy for a volatile, fragmented business environment. West Sussex: John Wiley \& Sons.

Tagliabue, J. (2003). Giovanni Agnelli, Fiat patriarch and a force in Italy dies at 81 . The New York Times-Online. Retrieved from: http://www.nytimes.com/2003/01/25/business/giovanniagnelli-fiat-patriarch-and-a-force-in-italy-dies-at-81.html. 
Tàpies, J., \& Fernández Moya, M. (2012). Values and longevity in family business: Evidence from a cross-cultural analysis. Journal of Family Business Management, 2(2), 130-146.

Uhlaner, L. M., van Goor-Balk, H. J. M., \& Masurel, E. (2004). Family business and corporate social responsibility in a sample of Dutch firms. Journal of Small Business and Enterprise Development, 11(2), 186-194.

Verbeke, A., \& Greidanus, N. S. (2009). The end of the opportunism vs trust debate: Bounded reliability as a new envelope concept in research on MNE governance. Journal of International Business Studies, 40(9), 1471-1495.

Verbeke, A., \& Kano, L. (2010). Transaction cost economics (TCE) and the family firm. Entrepreneurship Theory and Practice, 34(6), 1173-1182.

Verbeke, A., \& Kano, L. (2012). The transaction cost economics theory of the family firm: Family-based human asset specificity and the bifurcation bias. Entrepreneurship Theory and Practice, 36(6), 1183-1205.

Volpato, G. (2008). Fiat Group Automobiles: Le nuove sfide. Bologna: Il Mulino.

Ward, J. L. (2004). Perpetuating the family business: 50 lessons learned from long-lasting success. New York: Palgrave Macmillan.

Westermann-Behaylo, M. K., Rehbein, K., \& Fort, T. (2015). Enhancing the concept of corporate diplomacy: Encompassing political corporate social responsibility, international relations, and peace through commerce. Academy of Management Perspectives, 29(4), 387-404.

Westwood, R. (1997). Harmony and patriarchy: The cultural basis for 'paternalistic headship' among the overseas Chinese. Organization Studies, 18(3), 445-480.

Williamson, O. E. (1981). The modern corporation: origins, evolution, attributes. Journal of Economic Literature, 19(4), 1537-1568.

Williamson, O. E. (1996). The Mechanisms of Governance. New York: Oxford University Press.

Wislocki, A. (2017). Gorgona: the wine made by prisoners. Decanter Online. Retrieved from: http://www.decanter.com/features/gorgona-tuscanys-island-white-365678/.

WorldAtlas. (2018). The oldest companies still operating today. Retrieved from https://www.worldatlas.com/articles/the-oldest-companies-still-operating-today.html.

Zavyalova, A., Pfarrer, M. D., Reger, R. K., \& Shapiro, D. L. (2012). Managing the message: The effects of firm actions and industry spillovers on media coverage following wrongdoing. Academy of Management Journal, 55(5), 1079-1101. 


\section{Table 1. The corporate diplomacy tripod in family firms: Objectives and mechanisms}

\begin{tabular}{|c|c|c|c|}
\hline & Step 1: Reciprocal familiarization & Step 2: Mutual acceptance & Step 3: Mutual engagement \\
\hline Macro & $\begin{array}{l}\text { Objectives: } \\
\text { - Enhancing familiarity with features and } \\
\text { capabilities of a broad range of } \\
\text { stakeholders } \\
\text { - Educating external stakeholders on the } \\
\text { firm } \\
\text { Mechanisms: } \\
\text { - Scanning of macro-level } \\
\text { changes/contextual awareness } \\
\text { - Considering a broad set of stakeholders } \\
\text { as relevant to decision-making (incl. non- } \\
\text { family/non-kin-controlled) } \\
\text { - Evaluating continued relevance of } \\
\text { existing stakeholders } \\
\text { - Communicating relevant information } \\
\text { (value proposition/family identity) } \\
\text { through public channels }\end{array}$ & $\begin{array}{l}\text { Objectives: } \\
\text { - Recognizing a fundamental } \\
\text { similarity in value systems of } \\
\text { the family firm and external } \\
\text { stakeholders } \\
\text { Mechanisms: } \\
\text { - Developing the firm's reputation } \\
\text { for honest business dealings } \\
\text { - Broad-based relationship } \\
\text { building } \\
\text { - Strengthening functional links } \\
\text { with relevant/new stakeholders } \\
\text { (potentially without a family } \\
\text { connection) during periods of } \\
\text { macro-level shifts }\end{array}$ & $\begin{array}{l}\text { Objectives: } \\
\text { - Establishing the firm as an attractive } \\
\text { business partner and valuable } \\
\text { community member in relevant } \\
\text { markets } \\
\text { Mechanisms: } \\
\text { - Solidifying partnerships with a variety } \\
\text { of relevant business actors through } \\
\text { asset-specific investments } \\
\text { - Investing in multiple communities } \\
\text { where the firm operates } \\
\text { - Creating shared values and symbols } \\
\text { Direct involvement of family/senior } \\
\text { family firm leaders with relevant } \\
\text { actors (regulators/policy } \\
\text { makers/thought leaders) }\end{array}$ \\
\hline Firm & $\begin{array}{l}\text { Objectives: } \\
\text { - Improving familiarity with non-family } \\
\text { managers' conduct and expertise } \\
\text { - Transferring idiosyncratic knowledge } \\
\text { about the firm to non-family managers } \\
\text { Mechanisms: } \\
\text { - Formal commitment to information } \\
\text { exchange/access } \\
\text { - Sharing family documentation/archives } \\
\text { - Informal socialization (joint events) }\end{array}$ & $\begin{array}{l}\text { Objectives: } \\
\text { - Enhancing the similarity in } \\
\text { value systems among the family, } \\
\text { the firm, and non-family } \\
\text { employees } \\
\text { - Enacting these shared values } \\
\text { through the firm's strategy } \\
\text { Mechanisms: } \\
\text { - Explicit recognition of expertise } \\
\text { and value of non-family } \\
\text { managers } \\
\text { - Attaching full legitimacy to } \\
\text { decisions delegated to non- } \\
\text { family managers } \\
\text { - Non-family managers accept } \\
\text { core values of the family as } \\
\text { underlying principles of } \\
\text { governance }\end{array}$ & $\begin{array}{l}\text { Mechanisms: } \\
\text { - Informal cultivation of mutual } \\
\text { commitment } \\
\text { - Multi-level communication lines to } \\
\text { solicit and implement feedback and } \\
\text { ideas } \\
\text { - Meritocracy } \\
\text { - Formal sharing of awards and } \\
\text { liabilities among family and non- } \\
\text { family employees }\end{array}$ \\
\hline TG & $\begin{array}{l}\text { Objectives: } \\
\text { - Familiarizing present generation of } \\
\text { family leaders/stakeholders with } \\
\text { conduct/expertise/worldview of } \\
\text { upcoming generations } \\
\text { - Transferring idiosyncratic knowledge } \\
\text { about the firm to the next generation(s) } \\
\text { Mechanisms: } \\
\text { - Formal documents outlining the firm's } \\
\text { values, organization, governance } \\
\text { principles } \\
\text { - Family meetings/events } \\
\text { - Family intranet } \\
\text { - Family-specific publications } \\
\text { - Artefacts } \\
\text { - Cohabitation/co-location }\end{array}$ & $\begin{array}{l}\text { Objectives: } \\
\text { - New generation recognizes the } \\
\text { firm's values system } \\
\text { - Current generation recognizes } \\
\text { the upcoming generation's } \\
\text { potential unique contribution } \\
\\
\text { Mechanisms: } \\
\text { - Informal socializing through } \\
\text { joint events } \\
\text { - Mentorship programs } \\
\text { gormal 'sign off' on values and } \\
\text { - Building flexibility into guiding } \\
\text { principles to accommodate } \\
\text { future generations }\end{array}$ & $\begin{array}{l}\text { Objectives: } \\
\text { - Upcoming generations become } \\
\text { involved/contribute to the firm } \\
\text { - Current generation commits to } \\
\text { developing and growing the upcoming } \\
\text { generation(s) } \\
\text { Mechanisms: } \\
\text { - Internship programs } \\
\text { - Formally exchanging ideas/soliciting } \\
\text { ideas from younger generation } \\
\text { - Organizing cross-generational } \\
\text { technical forums } \\
\text { - Establishing formal career plans for } \\
\text { family members entering the firm } \\
\text { - Cross-generational collaboration on } \\
\text { strategic projects }\end{array}$ \\
\hline
\end{tabular}

